\title{
Feeding of Mesopodopsis slabberi (Crustacea, Mysidacea) on naturally occurring phytoplankton
}

\author{
P. Webb, R. Perissinotto* \& T. H. Wooldridge \\ University of Port Elizabeth, Institute for Coastal Research and Department of Zoology, PO Box 1600, Port Elizabeth 6000, \\ South Africa
}

\begin{abstract}
Laboratory studies on Mesopodopsis slabberi feeding on phytoplankton occurring naturally in Algoa Bay, South Africa, were run in order to determine ingestion rates in various monospecific phytoplankton concentrations and to determine possible differences between rates of ingestion between sexes, size classes, and day/night feeding on 2 diatom species. Increasing food supply was accompanied by a linear ingestion response during the first $3 \mathrm{~h}$ of feeding without clear upper or lower thresholds. Minimal ingestion followed this initial period of active feeding. M. slabberi, when offered mixtures of Anaulus birostratus and Asterionella glacialis, selected the numerically dominant diatom. A. glacialis forms a large spiral colony of cells and data suggest size selectivity, as it was selected for by $M$. slabberi when numerically dominant (cells $\mathrm{ml}^{-1}$ ) in the mixture even though the number of colonies was less than the number of $A$. birostratus cells present. Association between apparent shoreward migration by $M$. slabberi to close outside the breaker line at night and the distribution of food material by rip current circulation is postulated. The possibilities of selective grazing by $M$. slabberi influencing phytoplankton community structure, and the possible exclusion of persistent diatom accumulations behind the breaker line through grazing pressure, are noted.
\end{abstract}

\section{INTRODUCTION}

Mesopodopsis slabberi is the most abundant mysid found at night behind the breakerline off Eastern Cape beaches, South Africa (Wooldridge 1983). This species migrates closer inshore after dark when diatom accumulations disperse from surface waters in the surf zone (McLachlan \& Lewin 1981, Sloff et al. 1984). These diatom accumulations are mostly Anaulus birostratus but sporadic high concentrations of Asterionella glacialis and Aulacodiscus kittonii also occur (Talbot 1986).

The dynamics of diatom patch formation and dispersion has been intensively studied by Talbot \& Bate (1986) in the surf of the Sundays River Beach, Algoa Bay, South Africa. Diatoms accumulate in the surface layer adjacent to rip currents by day but begin to disperse in the late afternoon and are absent from the surface layer at night. Talbot \& Bate (1986) suggested the main feature of this day-night rhythmic sequence to be vertical migration of cells, i.e. alternation of their life

\footnotetext{
- Present address: Oceanography Department, Dalhousie University, Halifax, Nova Scotia B3H 4J1, Canada
}

mode from epipsammic at night to planktonic by day, with periodic breaks in this cycle by dispersive offshore transort. Talbot \& Bate (1986) proposed that air bubbles and foam formed by toppling wave crests are the physical forcing functions responsible for the observed vertical stratification of Anaulus birostratus during the day with physiological changes (clay coat formation) causing precipitation at night. During the day/night change between surface and epipsammic habitats cells may be transported out of the surf zone by rip currents and deposited behind the breaker line when these currents dissipate. Detritus is also transported out of the surf zone and deposited in this manner (Clutter 1966).

Beaches can be classified into 3 basic types (Short \& Wright 1983), of which profiles intermediate between high energy dissipative and low energy reflective types are common at Sundays River beach. Such beaches have unstable configurations and experience jump shifts in the position of the breaker line in response to changes in wave energy which cause shoreward or offshore movement of longshore bars (Wright et al. 1979). Shoreward shifts in the breaker line can reduce the area of the surf zone by as much as $70 \%$ (Talbot 1986) and after such shifts diatoms left outside the 
breaker line are expected to sink out of the surface layer. In this manner a large percentage of the surface population may enter the nearshore water circulation (Talbot 1986).

Wooldridge (1983) suggested that Mesopodopsis slabberi fed on surfzone phytoplankton, and that seaward transport of phytoplankton from the surf via rip currents would result in a rich supply of cells behind the breaker line which may be exploited by mysids after dark when they migrate shorewards. Mysids are generally omnivorous, feeding either raptorially or filter feeding on suspended organic matter (Mauchline 1980 ) and available data suggest that $M$. slabberi does not deviate from this pattern (Wooldridge 1983).

Mysis relicta is considered to be a major grazer of phytoplankton in Lake Michigan (Bowers \& Grossnickle 1978) and in Lake Vattern, Sweden (Stalberg 1933), but most mysid feeding experiments to date have dealt with predation on zooplankton (Parker 1979, Cooper \& Goldman 1980, Murtaugh 1981, Fulton 1982, Folt et al. 1982, Johnston \& Lasenby 1982) and there are currently insufficient data to allow a clear understanding of the dynamics of phytoplankton grazing by these animals. This study was designed to investigate some aspects of the feeding behaviour of Mesopodopsis slabberi on the most common accummulation-forming diatom species occuring in Algoa Bay. The study forms part of a larger programme of research into the energetics of sandy beach flora and fauna off Eastern Cape beaches (McLachlan \& Bate 1985).

\section{MATERLALS AND METHODS}

Field collection. Mesopodopsis slabberi were collected in both summer and winter from the lower Sundays estuary, Algoa Bay, South Africa, (salinity $33 \%$ ) using a $1 \mathrm{~mm}$ mesh seine net. Animals were transported in $20 \mathrm{l}$ buckets to the laboratory and kept at ambient temperature.

The diatoms Anaulus birostratus and Asterionella glacialis occur in rich accumulations in the Sundays Beach surf zone and were collected from surface foam generated through wave action. A. birostratus forms rectangular cells ranging in size from $5 \times 11 \times 14 \mu \mathrm{m}$ to $9 \times 22 \times 58 \mu \mathrm{m}$ while $A$. glacialis forms spiral colonies of varying length, but the smallest colonies used in feeding experiments were always larger than the largest $A$. birostratus cells present.

Laboratory preparation. Foam samples were filtered through a $200 \mu \mathrm{m}$ mesh sieve to remove larger zooplankters which may have been present. The phytoplankton was allowed to settle overnight before specific concentrations were made by decantation or by dilution of sample stock and seawater. Experimental concentrations of phytoplankton ranged from $1.76 \times 10^{4}$ to $3.48 \times 10^{5}$ cells $\mathrm{ml}^{-1}$. These values reflect a range of cell concentrations from the highest recorded in the surf zone to the lowest reproducible $1<10 \%$ variation) counts obtained with a haemocytometer using 8 replicates.

Anaulus birostratus divides most actively in the early morning (Talbot \& Bate 1986). Experiments were not undertaken during this time, so that changes in cell concentrations in control beakers were minimised.

Experiments were carried out on the effect of phytoplankton cell concentrations on rate of mysid ingestion using Anaulus birostratus at winter temperatures of 16 to $19^{\circ} \mathrm{C}$ and at the summer temperature of $23^{\circ} \mathrm{C}$. Asterionella glacialis was used in feeding experiments at $19^{\circ} \mathrm{C}$ as monospecific accumulations of this diatom occurred infrequently and only during late winter.

Experimental procedure. Four 11 replicate jars containing 5 mysids each (sexes separate) constituted each set of 6 monospecific Anaulus birostratus and 6 Asterionella glacialis experimental concentrations for experiments run over $3 \mathrm{~h}$. Mysids were excluded in the additional control jar provided for each set.

Temporal studies were run at 2 different Anaulus birostratus concentrations $\left(8.73 \times 10^{4}\right.$ and $1.8 \times 10^{4}$ cells $\mathrm{m}^{-1}$ ) to observe changes in ingestion rate. Experimental sets were analysed after $2 \mathrm{~h}$ intervals up to $12 \mathrm{~h}$. One control beaker without mysids was prepared for each set and 2 experimental jars of each set of 4 were stirred manually to enable comparison of the rate of ingestion between suspended and settled algae.

Experiments were also designed to establish possible differences between rates of ingestion by Mesopodopsis slabberi: (1) between sexes, (2) between diatom species, (3) between day and night.

Adult mysids used for food selectivity experiments were separated into sexes of the same mass and size class (10.5 mm in length), placed in a 11 mixture of Anaulus birostratus and Asterionella glacialis (respective initial concentrations $3.6 \times 10^{4}$ and $1.5 \times 10^{5}$ cells $\mathrm{ml}^{-1}$ and allowed to feed for $3 \mathrm{~h}$ in daylight. Twenty experimental jars were used and 2 controls kept. The experiment was repeated at night using fresh mysids. Data for feeding on a mixed culture of $A$. birostratus and $A$. glacialis, where $A$. birostratus was the numerically dominant diatom, were obtained in the same manner (respective initial concentrations $7.8 \times 10^{4}$ and $1.4 \times 10^{4}$ cells $\mathrm{ml}^{-1}$ ).

Sub-samples were taken at the beginning and end of each run to determine changes in phytoplankton concentration in experimental and control jars. The contents of the jars were poured through a $200 \mu \mathrm{m}$ sieve at the end of each run to thoroughly homogenise the suspension and remove the mysids before analysis. 
Random sub-samples $(5 \mathrm{ml})$ were taken using a $0.5 \mathrm{~cm}^{2}$ diameter glass tube which sampled all levels of the suspension, thus limiting possible error due to vertical stratification. The sub-samples were preserved immediately using 5 drops of Lugol's solution. Cell counts were made using the haemocytometer technique described by Lund et al. (1958). A minimum of 8 counts per sub-sample were taken and if the total number of cells counted was less than 300, further counts were made.

Ingestion rates were derived as arithmetical relations which may be assumed to provide reasonable estimates as long as the difference between initial and final concentrations in the feeding experiment is kept to a reasonable minimum (Paffenhöfer 1971). Initial and final algal concentrations in present feeding experiments were never more than $12.5 \%$ above or below the average food concentration, which is less than the value $(25 \%)$ quoted by Paffenhöfer (1971).

Data were analysed using BMDP statistical packages (Dixon et al. 1981). t-tests were used to analyse the significance of differences between data variables (Program 3D). BMDP program PAR was used for non-linear regression analyses.

Experiments to compare ingestion between 5 different Mesopodopsis slabberi size classes were also run to give an indication as to the relationship between $M$. slabberi size and quantity of phytoplankton eaten (food concentration $=3.0 \times 10^{5}$ cells $\mathrm{ml}^{-1}$ ). Female mysids were used for all size classes except for the newly hatched juveniles, where sexes were not separated.

Starved Mesopodopsis slabberi were placed in a sus- pension of Anaulus birostratus (concentration = $2.22 \times 10^{4}$ cells $\mathrm{ml}^{-1}$ ) and allowed to feed. Ten specimens were removed every $10 \mathrm{~min}$ and examined under a dissecting microscope at $10 \times$ magnification. Filling of proventriculus, gut, gastric glands and the colour of the contents was observed and noted.

Observation of gut clearing was made after mysids had been fed Anaulus birostratus. Between 9 und 20 mysids per sample were examined at $30 \mathrm{~min}$ intervals under a dissecting microscope at $10 \times$ magnification. The proventriculus, gut and gastric glands were each examined to determine whether they were empty. Numbers of mysids with empty sections of gut were expressed as a percentage of the total number sampled.

The gut contents of freshly caught mysids, collected after dark off the Sundays River Beach, were examined under a compound microscope $(\times 400)$ to determine the type of food ingested in the field.

\section{RESULTS}

Significant changes in Anaulus birostratus and Asterionella glacialis cell concentrations were not observed in control beakers over the experimental periods ( 3 to $12 \mathrm{~h}$ ) with the coefficient of variation for cell counts always being lower than $4 \%$.

Although differences in feeding rates were apparent, statistical comparison of ingestion rate data at 16,19 and $23>C$ showed no significant difference at the $95 \%$
Fig. 1. Mesopodopsis slabberi. Ingestion of Anaulus birostratus (cells $\times 10^{6}$ ) per mysid relative to food concentration. Dashed lines indicate $95 \%$ confidence levels

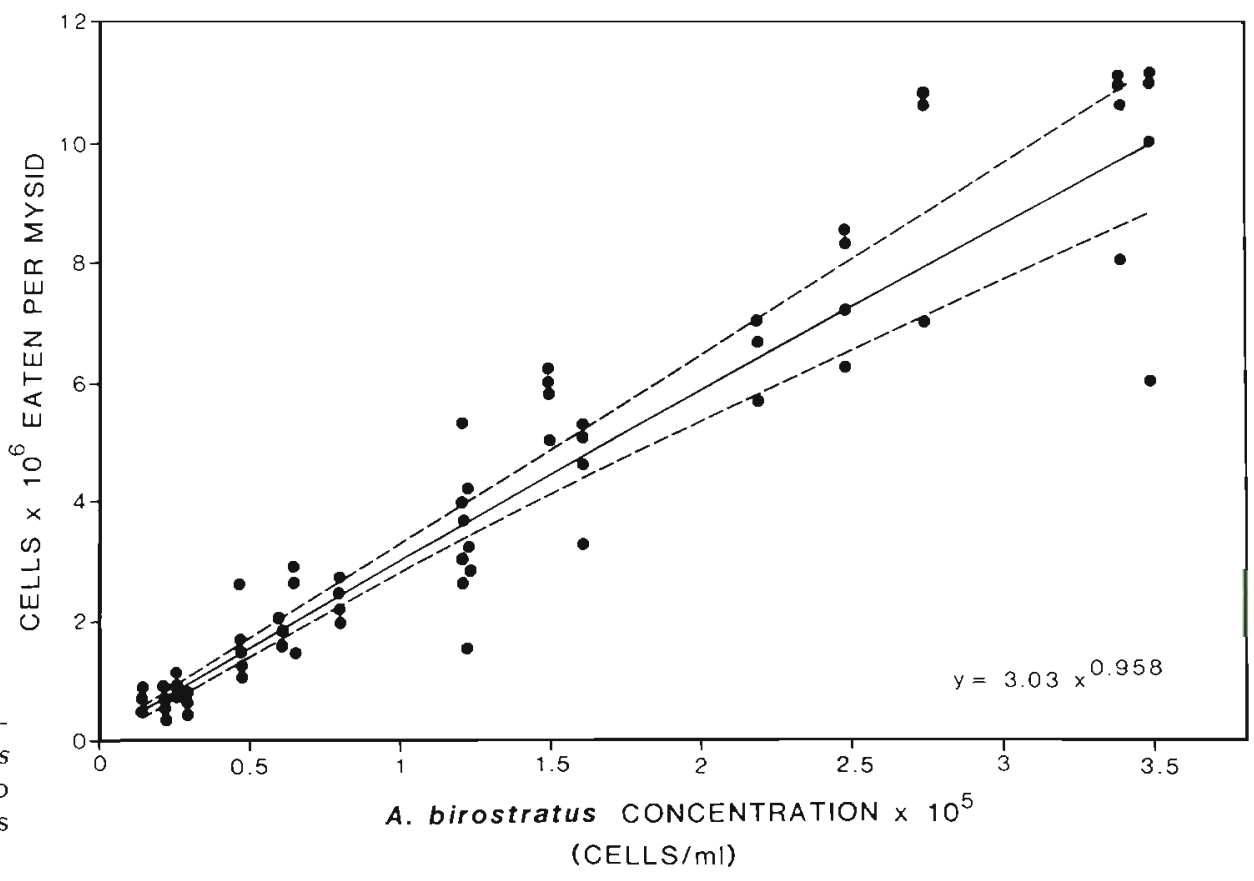




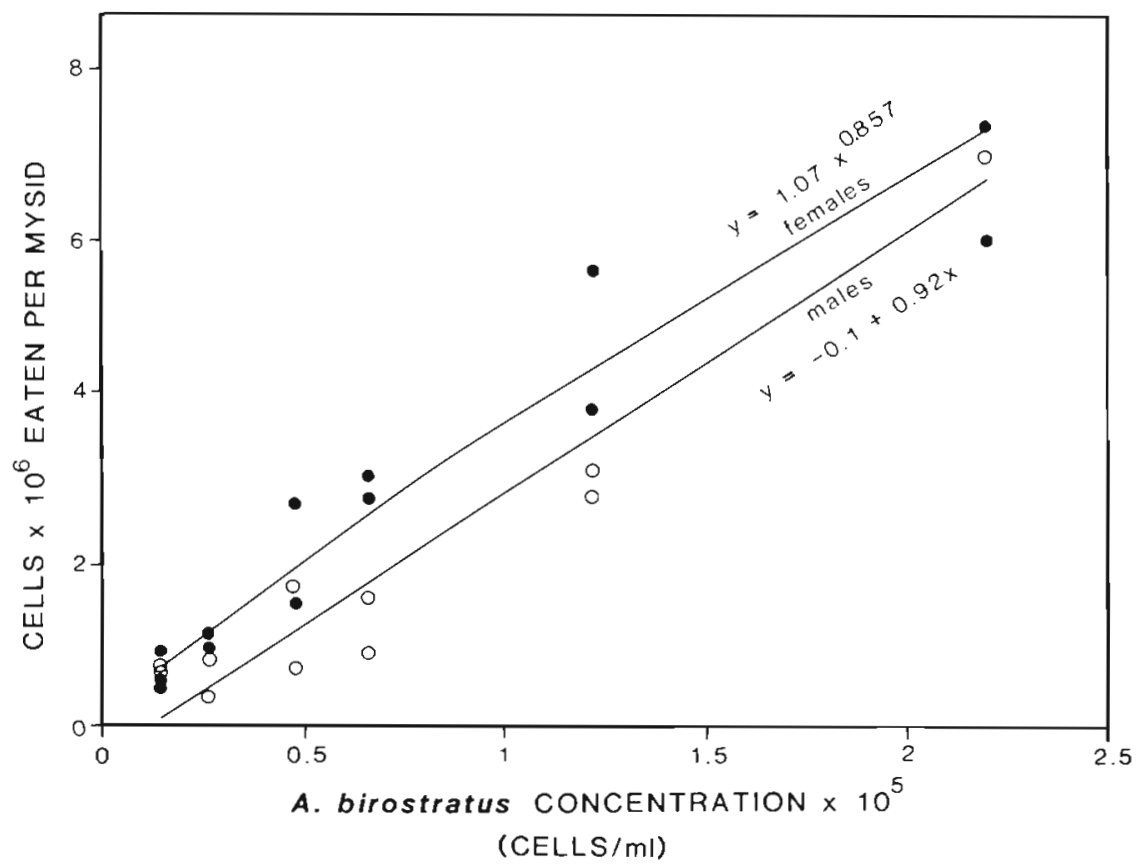

Fig. 2. Mesopodopsis slabberi. Ingestion of Anaulus birostratus per male and female relative to food concentration level (slope: $p>0.5$; y intercept : $p>0.5$ ). Minimisation of least-square variance showed a power expression as the best fit for the pooled 16,19 and $23^{\circ} \mathrm{C}$ experimental data ( $\mathrm{r}=0.96, \mathrm{n}=66$ ). Linear regression of data showed a poorer fit ( $\mathrm{r}=0.95, \mathrm{n}=66)$, but no significant differences was found between the 2 models.

Michaelis-Menton and Ivlev equations were also fitted to the pooled data (Michaelis-Menton MSE $=0.85$; Ivlev without threshold MSE $=0.842$; Ivlev with threshold MSE $=0.86$ ). Mean square error (MSE) values indicate that the Ivlev equation with no feeding threshold provides the best fit, but there is no statistically significant difference between models.

Table 1. Mesopodopsis slabberi. t-test analysis of mysids grazing on Anaulus birostratus. No. of cells (mean of experimental replicates) eaten during $12 \mathrm{~h}$ experiments.

\begin{tabular}{|c|c|c|c|}
\hline $\begin{array}{l}\text { Experimental } \\
\text { condition }\end{array}$ & $\begin{array}{l}\text { Mean no. of cells } \\
\text { eaten }\left(\times 10^{7}\right)\end{array}$ & $t$ & $\mathrm{n}$ \\
\hline $\begin{array}{l}\text { Male } \\
\text { Female }\end{array}$ & $\begin{array}{l}2.4600 \\
3.1840\end{array}$ & $6.21^{\cdots}$ & 20 \\
\hline $\begin{array}{l}\text { Day } \\
\text { Night }\end{array}$ & $\begin{array}{l}2.7560 \\
2.9105\end{array}$ & $0.94 \mathrm{~ns}$ & 20 \\
\hline $\begin{array}{l}\text { Stirred } \\
\text { Unstirred }\end{array}$ & $\begin{array}{l}2.2030 \\
2.1640\end{array}$ & $0.12 \mathrm{~ns}$ & 12 \\
\hline $\begin{array}{c}\text { ns: not signifi } \\
\because \text { : Significant } \\
\because \text { : Significant }\end{array}$ & $\begin{array}{l}95 \% \text { level } \\
99 \% \text { level }\end{array}$ & & \\
\hline
\end{tabular}

Mesopodopsis slabberi ingestion rate of Anaulus birostratus over $3 \mathrm{~h}$ is illustrated in Fig. 1. Ingestion increased steadily from $0.2 \times 10^{6}$ cells mysid ${ }^{-1}$ at a food concentration of $2 \times 10^{4}$ cells $\mathrm{ml}^{-1}$ to $1.2 \times 10^{7}$ cells mysid $^{-1}$ at a food concentration of $3.48 \times 10^{5} \mathrm{cells} \mathrm{m}^{-1}$.

Fig. 2 shows the ingestion rates of male and female Mesopodopsis slabberi collected in winter and fed 6 different concentrations of Anaulus birostratus. A significant difference exists between ingestion rates of adult male and adult female $M$. slabberi of the same length (Table 1), with females ingesting more cells than males (t-test, $\mathrm{p}<0.01$ ).

Ingestion of Asterionella glacialis by Mesopodopsis slabberi is shown in Fig. 3. Rate of ingestion ranged

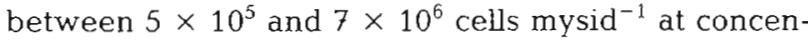
trations of $1.5 \times 10^{4}$ and $2.7 \times 10^{5}$ cells ml-1 respectively. Comparison of these data with data obtained from feeding mysids on Anaulus birostratus show no statistically significant difference (t-test, $p>0.05$ ) between the 2 diatom species.

Fig. 4 illustrates the relation between rates of ingestion per mysid in 2 concentrations of Anaulus birostratus. Curves were fitted to the data by least squares criteria and extrapolated by hand from the first reading to time zero, based on observations of gut filling. Ingestion was rapid over the first $2 \mathrm{~h}$, reaching $4 \times 10^{6}$ cells mysid $^{-1}$ at a food concentration of $8.73 \times 10^{4}$ cells ml $^{-1}$ and $3 \times 10^{5}$ cells mysid ${ }^{-1}$ at a food concentration of 1.82 $\times 10^{4}$ cells $\mathrm{ml}^{-1}$. Thereafter the number of cells ingested remained relatively unchanged, increasing only slightly over time. No difference in feeding rate was found between stirred experimental jars and those 
Fig. 3. Mesopodopsis slabberi. Ingestion of Asterionella glacialis per mysid relative to food concentration. Dashed lines indicate $95 \%$ confidence levels
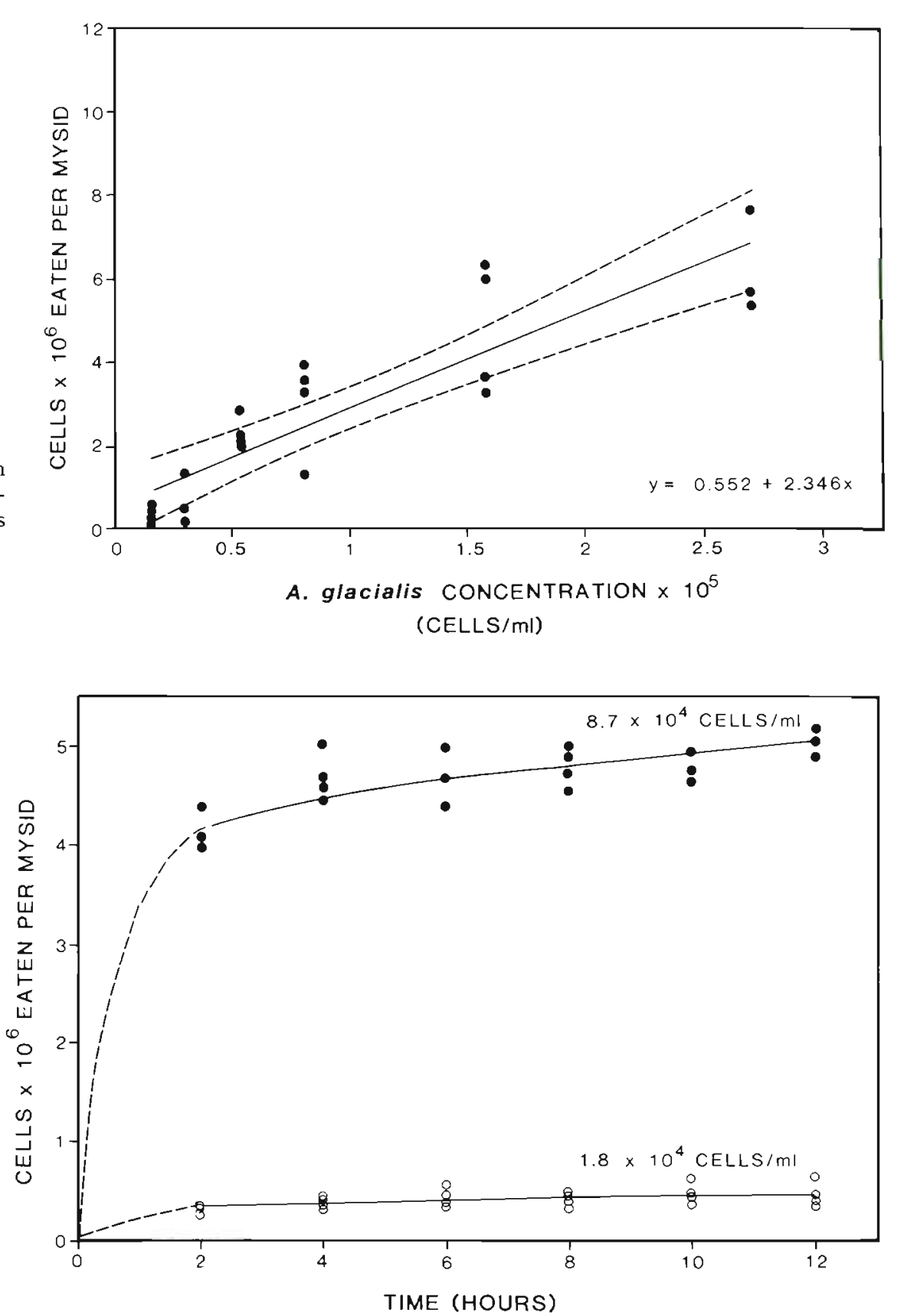

TIME (HOURS)
Fig. 4. Mesopodopsis slabberi. Ingestion of Anawlus birostratus per mysid in 2 food concentrations versus time allowed to settle (t-test, $p>0.05$ ). There was also no statistical difference between day and night feeding rate (Table 1 ).

Mixed algae experiments showed a significant difference between the algal species ingested. There was no difference between the number of Anaulus birostratus cells in control and experimental jars after experimental runs in which Asterionella glacialis was the numerically dominant diatom in the mixture (Table 2). However, a highly significant difference existed between $A$. glacialis control and experimental jars, demonstrating a marked selection for A. glacialis.
Experiments using mixtures with $A$. birostratus as the numerically dominant diatom show a switch to selection for $A$. birostratus (Table 2).

The relation between cell ingestion rate and mysid length is shown in Fig. 5. Mysid size classes ranged between 3 and $13 \mathrm{~mm}$. Maximum size corresponds to the largest adults in field collections while the minimum size corresponds to newly hatched juveniles. Ingestion rate increased exponentially with increase in mysid length described by the equation: $y=2.73$ $\mathrm{e}^{0 \cdot 113 \mathrm{x}}$

Observations of packing and colouration of gut con- 


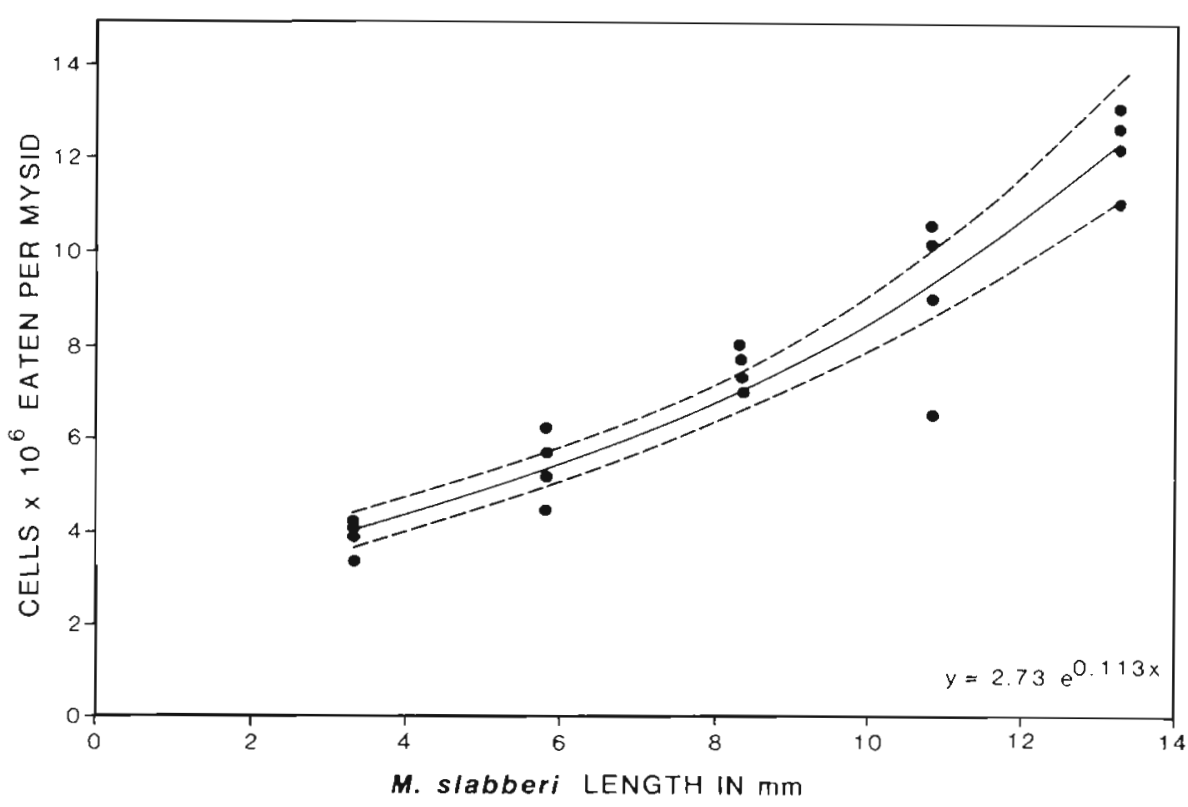

Fig. 5. Mesopodopsis slabberi. Ingestion of Asterionella glacialis per mysid relative to mysid length. Dashed lines indicate $95 \%$ confidence levels
Table 2. Mesopodopsis slabberi. t-test analysis of mysids grazing on mixed phytoplankton cultures. Final mean concentrations of Anaulis biostratus and Asterionella glacialis after 3 $\mathrm{h}$ runs. Numerically dominant diatom is given in bold type

\begin{tabular}{|c|c|c|c|c|}
\hline Diatom & $\begin{array}{c}\text { Control } \\
\text { (cells } \mathrm{ml}^{-1} \text { ) }\end{array}$ & $\begin{array}{l}\text { Experiment } \\
\text { (cells } \mathrm{ml}^{-1} \text { ) }\end{array}$ & $\mathrm{t}$ & $\mathrm{n}$ \\
\hline A. birostratus & $7.81 \times 10^{4}$ & $5.88 \times 10^{4}$ & $70.29 \cdots$ & 21 \\
\hline A. glacialis & $1.43 \times 10^{4}$ & $1.39 \times 10^{4}$ & $0.86 \mathrm{~ns}$ & 21 \\
\hline A. birostratus & $3.69 \times 10^{4}$ & $3.71 \times 10^{4}$ & $0.20 \mathrm{~ns}$ & 27 \\
\hline A. glacialis & $1.44 \times 10^{5}$ & $1.16 \times 10^{5}$ & $17.94^{\cdots}$ & 27 \\
\hline \multicolumn{5}{|c|}{ ns: not significant } \\
\hline \multicolumn{5}{|c|}{$\because$ Significant at $95 \%$ level } \\
\hline \multicolumn{5}{|c|}{$\because$ : Significant at $99 \%$ level } \\
\hline
\end{tabular}

tents of mysids fed Anaulus birostratus (concentration of $2.2 \times 10^{4}$ cells $\mathrm{ml}^{-1}$ ) are illustrated in Table 3 . The foregut filled within $5 \mathrm{~min}$ and faecal pellets began forming after $30 \mathrm{~min}$. The contents of the gastric glands of all mysids sampled began changing from green to yellow after $90 \mathrm{~min}$. After $3.5 \mathrm{~h}$ the contents of all mysids sampled were yellow, turning brown after $4.75 \mathrm{~h}$.

Gut clearance of Mesopodopsis slabberi after being fed Anaulus birostratus is shown in Table 4. All portions of the gut of all mysids sampled had cleared within $14 \mathrm{~h}$. The proventriculus of all mysids sampled had emptied within an hour, while the rest of the gut, excluding gastric glands, took $1.5 \mathrm{~h}$ to clear.

Examination of stomach contents of Mesopodopsis slabberi collected behind the breaker line at night revealed largely unidentifable, amorphorus detritus.

Table 3. Mesopodopsis slabberi. Gut filling when feeding on Anaulus birostratus through time (diatom concentration $2.22 \times 10^{4}$ cells $\mathrm{ml}^{-1}$ ). Numbers are no. of mysids out of 10 with food of the colouration indicated in the gastric gland and the presence of food in the hindgut of individuals sampled (green to yellow)

\begin{tabular}{|c|c|c|c|c|c|c|}
\hline \multirow[t]{2}{*}{ Time } & \multirow[t]{2}{*}{ Foregut } & \multicolumn{4}{|c|}{ Gastric gland } & \multirow{2}{*}{$\begin{array}{l}\text { Hindgut (faecal } \\
\text { pellets) }\end{array}$} \\
\hline & & Tinged green & Green/yellow & Yellow & Brown & \\
\hline 0 & Empty & Empty & Empty & Empty & Empty & Empty \\
\hline $5 \min$ & Full & 5 & & & & Empty \\
\hline $15 \min$ & Full & 4 & 5 & 1 & & Empty \\
\hline $30 \mathrm{~min}$ & Full & 2 & 4 & 4 & & 3 \\
\hline $1 \mathrm{~h}$ & Full & 1 & 4 & 5 & & 4 \\
\hline $1 \mathrm{~h} 30 \mathrm{~min}$ & Full & & 3 & 6 & & 6 \\
\hline $2 \mathrm{~h}$ & Full & & 2 & 7 & & 6 \\
\hline $2 \mathrm{~h} 45 \mathrm{~min}$ & Full & & 1 & 7 & 2 & 6 \\
\hline $3 \mathrm{~h} 30 \mathrm{~min}$ & Full & & & 6 & 4 & 7 \\
\hline $4 \mathrm{~h} 10 \mathrm{~min}$ & Full & & & 5 & 5 & 8 \\
\hline $4 \mathrm{~h} 45 \mathrm{~min}$ & Full & & & & 10 & 8 \\
\hline
\end{tabular}


Table 4. Mesopodopsis slabberi. Gut clearing after being fed Anaulus birostratus (concentration $2.22 \times 10^{4}$ cells $\mathrm{ml}^{-1}$ ). Figures indicate percentage of mysids sampled having empty sections of gut. Maximum 20, minimum 9 mysids examined per sample

\begin{tabular}{|c|c|c|c|}
\hline Time & Proventriculus & Gut & Gastric gland \\
\hline Start & Full & Full & Full \\
\hline $30 \mathrm{~min}$ & $90 \%$ empty & $10 \%$ empty & Full \\
\hline $1 \mathrm{~h}$ & $100 \%$ empty & $65 \%$ empty & Full \\
\hline $1 \mathrm{~h} 30 \mathrm{~min}$ & $100 \%$ empty & $100 \%$ empty & Full \\
\hline $2 \mathrm{~h}$ & $100 \%$ empty & $100 \%$ empty & $6 \%$ empty \\
\hline $2 \mathrm{~h} 30 \mathrm{~min}$ & $100 \%$ empty & $100 \%$ empty & $19 \%$ empty \\
\hline $3 \mathrm{~h} 30 \mathrm{~min}$ & $100 \%$ empty & $100 \%$ empty & $25 \%$ empty \\
\hline $4 \mathrm{~h} 30 \mathrm{~min}$ & $100 \%$ empty & $100 \%$ empty & $27 \%$ empty \\
\hline $5 \mathrm{~h} 30 \mathrm{~min}$ & $100 \%$ empty & $100 \%$ empty & $20 \%$ empty \\
\hline $6 \mathrm{~h} 30 \mathrm{~min}$ & $100 \%$ empty & $100 \%$ empty & $30 \%$ empty \\
\hline $7 \mathrm{~h} 30 \mathrm{~min}$ & $100 \%$ empty & $100 \%$ empty & $30 \%$ empty \\
\hline $8 \mathrm{~h} 30 \mathrm{~min}$ & $100 \%$ empty & $100 \%$ empty & $40 \%$ empty \\
\hline $9 \mathrm{~h} 30 \mathrm{~min}$ & $100 \%$ empty & $100 \%$ empty & $56 \%$ empty \\
\hline $14 \mathrm{~h}$ & $100 \%$ empty & $100 \%$ empty & $100 \%$ empty \\
\hline
\end{tabular}

\section{DISCUSSION}

There is a paucity of published quantitative data on ingestion and filtration rates of mysids. However comparisons may be made with other pelagic filter feeders. In the present study, arithmetic differences between initial and final cell concentrations were used to calculate the number of cells ingested. This was possible as the number of mysids used, as well as the volumes and concentrations of food offered, kept concentrations on average within $5 \%$ above and below the mean cell concentration. The maximum range recorded was $12.5 \%$ above and below the mean cell concentration.

Several response curves relate zooplankton ingestion rates to various concentrations of food particles, e.g. increased ingestion rate in direct proportion to increased food concentration up to a saturation point (Frost 1972), weak evidence for saturation levels (Deason 1980), and proportional ingestion rates without any transition of feeding behaviour (Reeve \& Walter 1977, Mayzaud \& Poulet 1978, Huntley 1981).

Frost's (1972) work on the copepod Calanus pacificus feeding on monospecific cultures of centric diatoms showed an ingestion rate directly dependent on cell concentration and size at low food concentrations. At high food concentrations the rate is independent of concentration. His model assumes that ingestion rate for filter feeders such as copepods increases in direct proportion to increase in food concentration up to a saturation point.

Although this effect has been observed in other filter feeders (Gaudy 1974, Stuart 1986), several studies do not show evidence for saturated feeding. Experiments with Acartia hudsonica (Deason 1980) grazing on Skeletonema costatum showed that very high concentrations of diatoms are required before ingestion becomes maximal, and in many cases saturation is not reached. This is more evident in studies with naturally occuring suspensions where a critical concentration, with distinct transition of feeding behaviour, was rarely attained (Reeve \& Walter 1977, Mayzaud \& Poulet 1978, Huntley 1981).

A maximum ingestion rate for Mesopodopsis slabberi was not found by increasing prey cell concentrations up to $3.5 \times 10^{5}$ cells $\mathrm{ml}^{-1}$. Observations indicate that ingestion is in proportion to diatom concentration over $3 \mathrm{~h}$, even in concentrated suspensions from dense phytoplankton accumulations. Murtaugh (1985) has shown that Daphnia pularica gut residence time decreases with increase in food density when fed Cryptomonas erosa. This was evident even over a relatively small range of concentrations $\left(3.1\right.$ to $4.3 \times 10^{4}$ cells $\left.\mathrm{ml}^{-1}\right)$. Reduced gut residence time with increased food concentration is a mechanism which could facilitate density-dependent ingestion as shown by $M$. slabberi.

Fitting functional response models to the experimental data has shown no significant differences between linear regression and various curvilinear relations. Lehman (1976) notes that theories separating Ivlev, Michaelis-Menten and rectilinear equations are insufficiently supported and no one model has been statistically proved to be better than another. Difficulty in separating models is exacerbated as data obtained indicate no upper feeding threshold and because of lack of experimental data at low food concentrations.

Ingestion curves over $12 \mathrm{~h}$ showed minimal ingestion after an initial period of active feeding, independent of food concentration offered (Fig. 4). During this time, cell concentration in the high concentration experimental jars had decreased by $23 \%$ after $2 \mathrm{~h}$ and by $25 \%$ after $12 \mathrm{~h}$. In the low concentration experimental jars the concentration had dropped by $7 \%$ after $2 \mathrm{~h}$ and 
by $9 \%$ at the end of the experiment. Foraging theorists state that optimal filtering rates are reached at fairly low food concentrations and predict that once the gut of a filter feeder is filled, filtering would almost cease, with energy being expended only to maintain gut packing (McArthur 1972, Lehman 1976). Present data supports this prediction, but also suggest that digestive processes play a role in controlling filtering rate. Once the content of the gastric glands have turned yellow (Table 3), the mysid reduces its filtering rate to a low level. This seems independent of amount ingested (Fig. 4); hence digestion may play a complementary role to gut packing as a determining factor controlling filtering rate in Mesopodopsis slabberi.

Mesopodopsis slabberi, when offered a mixture of Anaulus birostratus cells and Asterionella glacialis colonies, selected A. glacialis when it was the numerically dominant diatom (cells $\mathrm{ml}^{-1}$ ), but selected $A$. birostratus when it was the dominant diatom in the mixture (Table 2). A. glacialis forms a spiral colony of cells much larger than individual $A$. birostratus cells and even when A. glacialis was the numerically dominant diatom (cells ml-1), the number of colonies was much less than individual $A$. birostratus cells. According to Siegfried \& Kopache (1980), selectivity patterns of herbivorous mysids represent capturability based on size rather than true preference. Selectivity changes have been explained by Lehman (1976) in terms of alterable filtering mesh size, effort due to water drag and energetic rewards. The capability to alter effective mesh size has been shown in Acartia tonsa (Wilson 1973) and Acartia clausi (Donaghay \& Small 1979). Within Lehman's (1976) explanatory framework, A. birostratus would be selected for at low concentrations of the larger algal colony as the energetic reward is greater than the extra energetic expenditure due to increased drag associated with reduced mesh size.

Bowers \& Grossnickle (1978) felt that differential grazing pressure through selectivity might be a mechanism influencing phytoplankton community composition. In this light, possible interactions between Mesopodopsis slabberi and the large diatoms Asterionella glacialis and Aulacodiscus kittonii require further investigation as both species are potentially capable of generating accumulations in the surf zone, but occur much less abundantly than Anaulus birostratus.

Gut content analysis of Mesopodopsis slabberi collected outside the breaker line at night has not shown significant diatom frustule representation. Nevertheless, as mysids completely macerate food, the largely unidentifiable gut contents could represent masticated diatom cells. This was borne out by examination of the stomach contents of mysids fed Anaulus birostratus in the laboratory. The high feeding rate of $M$. slabberi on diatoms in laboratory experiments also supports the possibility that diatoms could be an important food source for this species.

A large amount of non-motile material is deposited where rip currents slow down and disperse. Clutter (1966) suggested that the accumulation of a large amount of detrital food outside the breaker zone could be the major factor influencing the distribution of nearshore mysids such as Metamysidopsis elongata. Bowers \& Grossnickle (1978) and Grossnickle (1979) have shown that Mysis relicta in Lake Michigan feeds on phytoplankton at night by migrating to the subsurface layer containing maximum chlorophyll a concentrations. A similar feeding strategy, involving shoreward migration at night to behind the breaker line where rip currents deposit Anaulus birostratus and detrital food material, may be practised by Mesopodopsis slabberi. Wooldridge (1983) recorded an average density of $1000 \mathrm{M}$. slabberi $\mathrm{m}^{-3}$ behind the breaker line at night in Algoa Bay. On occasion swarms as dense as 15000 ind $\mathrm{m}^{-3}$ have been recorded and grazing pressure by $M$. slabberi may preclude the accumulation of $A$. birostratus populations behind the breaker line.

Acknowledgements. We thank Danie Venter for help with computer programming and Deo Winter for the use of his 'curvefit' and 'slope' programs. Renzo Perissinotto was supported financially by the South African Department of National Education.

\section{LITERATURE CITED}

Bowers, J. A., Grossnickle, N. E. (1978). The herbivorous habits of Mysis relicta in Lake Michigan. Limnol Oceanogr. 23: 767-776

Clutter, R. I. (1966). Zonation of nearshore mysids. Ecology 48: $200-208$

Cooper, S. D., Goldman, C. R. (1980). Opossum shrimp (Mysis relicta) predation on zooplankton. Can. J. Fish. Aquat. Sci. 37: 909-919

Deason, E. E. (1980). Grazing of Acartia hudasonica on Skeletonema costatum in Narrangasett Bay (USA): influence of food concentration and temperature. Mar. Biol. 60 101-113

Dixon, W. J., Brown, M. B., Engelman, L., Frane, J. W., Hill, M. A., Jennrich, R. I., Toporek, J. D. (1981). BMDP statistical software 1981. Univ. of California Press, Berkeley

Donaghay, P. L., Small, L. F. (1979). Food selection capabilities of the estuarine copepod Acartia clausi. Mar. Biol. 52: $137-146$

Folt, C. L., Rybock, J. T., Goldman, C. R. (1982). The effect of prey compositions and abundance on the predation rate and selectivity of Mysis relicta. Hydrobiologia 93: 133-143

Frost, B. W. (1972). Effect of size and concentration of food particles on the feeding behaviour of the marine planktonic copepod Calanus pacificus. Limnol. Oceanogr. 17 805-815 
Fulton, R. S., III. (1982). Predatory feeding of two marine mysids. Mar. Biol. 72: 183-191

Gaudy, R. (1974). Feeding of four species of pelagic copepods under experimental conditions. Mar. Biol. 25: 125-141

Grossnickle, N. E. (1979). Nocturnal feeding pattern of Mysis relicta in Lake Michigan, based on gut content fluorescence. Limnol. Oceanogr. 24: 777-780

Huntley, M. (1981). Non-selective, non-saturated feeding by three calanoid copepod species in the Labrador Sea. Limnol. Oceanogr. 26: 831-842

Johnston, N. T., Lasenby, D. C. (1982). Diet and feeding of Neomysis mercedis Holmes (Crustacea, Mysidacea) from the Fraser River Estuary, British Columbia. Can. J. Zool. 60: $813-824$

Lehman, J. T. (1976). The filter-feeder as an optimal forager, and the predicted shapes of feeding curves. Limnol. Oceanogr. 21: 501-516

Lund, J. W. G., Kipling, C., LeCren, E. D. (1958). The inverted microscope method of estimating algal numbers and the statistical basis of estimations by counting. Hydrobiologia 11: $143-170$

Mauchline, J. (1980). The biology of mysids and euphausids. In: Blaxter, J. H. S., Russell, F. S., Yonge, M. (ed.) Advances in Marine Biology, Vol. 18. Academic Press, New York, p. $1-369$

Mayzaud, P., Poulet, S. A. (1978). The importance of the time factor in the response of zooplankton to varying concentrations of naturally occurring particulate matter. Limnol. Oceanogr. 23: 1144-1154

McArthur, R. H. (1972). Geographical ecology. Patterns in the distribution of species. Harper and Row, London

McLachlan, A., Bate, G. (1985). Carbon budget for a high energy surf zone. Vie Milieu 34 (2/3): 67-77

McLachlan, A., Lewin, J. (1981). Observations on surf phytoplankton blooms along the coast of South Africa. Botanica mar. 24: 553-557

Murtaugh, P. A. (1981). Selective predation by Neomysis mercedis in Lake Washington. Limnol. Oceanogr. 26: 445-453

Murtaugh, P. A. (1985). The influence of food concentration and feeding rate on gut residence time of Daphnia. J. Plankton Res. 7: 415-420

Paffenhöfer, G.-A. (1971). Grazing and ingestion rates of nau- plii, copepodids, and adults of the marine planktonic copepod Calanus helgolandicus. Mar. Biol. 11; 286-298

Parker, J. I. (1979). Predation by Mysis relicta on Pontoporeia hoyi: a food chain link of potential importance in the Great Lakes. J. Great Lakes Res. 6: 164-166

Reeve, M. R., Walter, M. A. (1977). Observations on the existence of lower threshold and upper critical food concentrations for the copepod Acartia tonsa Dana J. exp. mar. Biol. Ecol. 29: 211-221

Short, A. D., Wright, L. D. (1983). Physical variability of sandy beaches. In: McLachlan, A., Erasmus, T. (ed.) Sandy beaches as ecosystems. Junk, The Hague, p. 133-144

Siegfried, C. A., Kopache, E. K. (1980). Feeding of Neomysis mercedis (Holmes). Biol. Bull. mar. biol, lab., Woods Hole 159: 193-205

Sloff, D. S., McLachlan, A., Bate, G. C. (1984). Spatial distribution and diel periodicity of Anaulus birostratus Grunow in the surf zone of a sandy beach in Algoa Bay, South Africa. Botanica mar. 27: 461-465

Stalberg, G. (1933). Beitrag for kenntnis der biologie von Mysis relicta des Vättern. Ark. Zool. 26: 1-29

Stuart, V. (1986). Feeding and metabolism of Euphausia lucens (Euphausiacea) in the southern Benguela current. Mar. Ecol. Prog. Ser. 30: 117-125

Talbot, M. M. B. (1986). The distribution of the surf diatom Anaulus birostratus in relation to nearshore circulation in an exposed beach/surf-zone ecosystem. Ph. D. dissertation, Univ. of Port Elizabeth

Talbot, M. M. B., Bate, G. C. (1986). Diel periodicities in cell characteristics of the surfzone diatom Anaulus birostratus: their role in the dynamics of cell patches. Mar. Ecol. Prog. Ser. 32: 81-89

Wilson, D. S. (1973). Food size selection among copepods. Ecology 54 : 909-914

Wooldridge, T. H. (1983). Ecology of beach and surf-zone mysid shrimps in the Eastern Cape, South Africa. In: McLachlan, A., Erasmus, T. (ed.) Sandy beaches as ecosystems. Junk, The Hague, p. 449-460

Wright, L. D., Chappel, J., Thom, B. G., Bradshaw, M. P., Cowell, P. (1979). Morphodynamics of reflective and dissipative beach and inshore systems: South Eastern Australia. Mar. Geol. 32: 105-140

This article was submitted to the editor; it was accepted for printing on March 25, 1987 